\title{
Uzaktan Öğrenenlerin Öğrenme Biçimlerinin İncelenmesi
}

\author{
Ilker USTA ${ }^{1}$
}

\section{Özet}

$\mathrm{Bu}$ araştırmanın amacı çevrimiçi tezsiz yüksek lisans programlarında öğrenim gören öğrencilerin öğrenme biçimlerini çalışma durumları, çalışılan sektör ve günde derslerine ayırdıkları süre değişkenleri açısından incelemektir. $\mathrm{Bu}$ araştırma tarama modelinde betimsel bir çalışmadır. Verilerin analizinde yüzde ve frekans kullanılmıştır. Öğrenme biçimlerini belirlemek üzere VARK öğrenme biçimleri envanteri kullanılmıştır. Araştırmanın örneklemini bir üniversitenin sosyal bilimler enstitüsüne bağlı çevrimiçi yürütülen altı program oluşturmaktadır. Öğrencilere elektronik ortamda oluşturulan anket aracılığıyla ulaşılmıştır. Araştırmaya 122 öğrenci katılmıştır. Araştırmaya katılan öğrencilerin çoğunluğu çalışmaktadır. Çalışan öğrencilerin ise 58'i kamu'da 45 ’i de özel sektörde çalışmaktadır. Öğrencilerin çoğunluğu derslerine günde 1-2 saat arası zaman ayırmaktadırlar. Araştırmaya katılan öğrencilerin en çok tercih ettikleri öğrenme biçimi kinestetik öğrenme biçimidir. Öğrenciler çoklu öğrenme biçimleri tercihinde de bulunmuşlardır. Çoklu öğrenme biçimleri içerisinde en çok tercih edilen öğrenme biçimi tüm alanları kapsayan VARK (Görsel, İşitsel, Okuma-yazma, Kinestetik) belirlenmiştir.

Anahtar Kelimeler: Uzaktan öğrenen, öğrenme biçimleri, VARK öğrenme stili, çevrimiçi program

\section{Investigation Of Learning Styles Of Distance Learners}

\begin{abstract}
The aim of this study is to determine the learning styles of the students who are studying in the non-thesis master's programs in terms of their working conditions, working sector and the time variables they devote to their courses. This research is a descriptive study in the screening model. Percentage and frequency were used in data analysis. VARK learning forms inventory was used to determine learning styles. The sample of the study consists of six online programs which are connected to the social sciences institute of a university. The students were reached through an electronic questionnaire via Internet. 122 students participated to study. The majority of the students who are participated to study are working. 58 of the working students work in the public sector and 45 in the private sector. The majority of the students spend 1-2 hours per day on their lessons. The most preferred learning styles among students is "kinesthetic" style. Students also preferred multimod learning styles. VARK (Visual, Audiovisual, Literacy, Kinesthetic) is the most preferred multimod style among students.
\end{abstract}

Keywords: Distance learners, learning styles, VARK learning style, online program

1 Dr. Öğr. Üyesi, Anadolu Üniversitesi Açıöğretim Fakültesi, Uzaktan Öğretim Bölümü, ilkerusta@anadolu.edu.tr 


\section{Giriş}

20. yüzyılda iki önemli teori olan ve eğitim modellerine yön veren, temelinde bireysel farklılıkların dikkate alınması gerektiği olan öğrenme biçimleri ve çoklu zekâ kuramı geliştirilmiştir. Öğrenme biçimleri teorisi psikoanalitik bağlaşımların kökünü oluşturmakla birlikte bireylerin problem çözme, ürün yaratma ve etkileşim gibi farklı düşünme ve hissetme yolları olarak nitelendirilen kavramlar üzerine yoğunlaşmıştır (Silver, Strong ve Perini, 1997, 22). Bu kavrama Keefe (1979) bir bireyin öğrenme çevresini nasıl algıladığı, onunla nasıl etkileşimde bulunduğu ve ona nasıl bir tepki verdiğini gösteren oldukça dengeli bilişsel, duyuşsal ve fizyolojik özelliklerinin bileşeni olarak tanımlarken Gregorc (1979) bireyin nasıl öğrendiğini ve bunu çevresine nasıl uyarladığını gösteren ayırt edici davranışlardan oluştuğu görüşündedir. Hunt (1979) öğrenme biçimini bir öğrencinin hangi öğretim koşullarında öğrenebileceğini tanımladığına inanarak açıklarken Honney ve Mumford (1982) bireyin öğrenme etkinliklerindeki tercihleri ile ilgili olarak açıklamıştır (Akt: Ülgen, 1995). Kolb (1984) öğrenme biçimlerini bireyin bilgiyi algılama ve işlemedeki tercih ettiği yöntem olarak tanımlarken Grasha (1996) ise öğrencinin bilgiyi edinme sürecindeki yeteneği ve öğrenme deneyimlerinin bir araya getirilmesi olarak tanımlamaktadır.

Tüm bu bakış açıları dikkate alınarak söylenebilir ki, öğrenme biçimi; bireyin öğrenme çevresinde bulunan, algıladığ tüm değişkenlere karşı gelişim özellikleri çerçevesinde gösterdiği kişiye özgü bilgiyi işleme tercihidir.

Her ne kadar son yıllarda öğrenme biçimlerine ilişkin eleştiriler bulunsa da, Graf, Kinshuk ve Liu (2009) çeşitli öğrenme yöntemleri ya da tercihleri olan öğrenciler hakkında öğretmenlere bilgi sağlama, öğrencilerin neden ve hangi durumlarda öğrenme güçlüğü çektiklerini belirleme ve öğrencilerin kendi öğrenme stillerinin farkına vararak öğrenmelerini etkileyen öğrenme sürecinin zayıf ve güçlü yanlarını anlamaları amacıyla çevrimiçi öğrenme ortamlarının öğrenme stillerinin dikkate alınarak düzenlenmesi gerektiğini belirtmektedirler. Bununla birlikte öğrencilerin çevrimiçi öğrenme ortamlarındaki eşzamansız tartışmalarını inceleyen Topçu (2008), öğretmenlerin öğrenme biçimleri ve kültürel bağlamların farkında olmasının öğrencilerin web temelli öğrenme ortamlarındaki performanslarını arttırmalarına yardımcı olduğu sonucunu elde etmiştir. Saeed, Yang ve Sinnappan (2009) ise günümüz öğrencilerinin öğrenme biçimlerinin esnek yapıda olduğunu ve bunların web teknolojilerini içeren öğretim stratejileri ile karşılanabildiğini belirtmektedirler.

\section{Vark Öğrenme Biçimleri Modeli}

VARK (V:visual-görsel; A:aural-işitsel; R:read,write-okuyarak,yazarak; K:kinestheticbedensel) öğrenme biçimleri bireylerin bilgi alışverişlerini nasıl yaptıklarını, bilgiyi işleme tercihlerinin neler olduğunu ortaya çıkarmayı amaçlamaktadır. VARK'ı oluşturan envanter sorularında farklı senaryolar yaratılarak, bireyin o durumda hangi tercihi yapacağını yanıtlaması istenir. Birey 
birden fazla yolu tercih edebileceğinden, birden fazla seçeneği işaretleyebilir ya da seçeneklerden hiçbirini uygun bulmuyorsa soruyu boş bırakabilmektedir (Fleming ve Mills, 1992).

Fleming, Kolb'un modelinden hareketle temel olarak görsel (V), işitsel (A), oku/yaz (R) ve kinestetik (K) gruplarını tanımlamış, ancak iki veya daha fazla öğrenme stilleri aynı ağılıkta olanları çok-tarzlı olarak kabul etmiştir (Leite, Svinicki ve Shi, 2010).

VARK modeli 3 ilkeye dayalı olarak kullanılmaktadır (Bahadori vd., 2011: 123):

- Tüm öğrencilerin öğrenebilme yeteneği vardır, fakat her birinin kendine ait farklı stili vardir.

- $\quad$ Öğrenciye özel öğrenme stili sunulduğunda öğrenme motivasyonu artar.

- $\quad$ Eğitime ilişkin kavramları en iyi öğrenme yolu; duygular ve farklı algılamalar yoluyla gerçekleşir.

$\mathrm{Bu}$ ilkeler 1şı̆̆ında, bilgilerin edinilmesi, algılanması ve işlenmesi görsel, işitsel, okuma ve kinestetik olmak üzere sinirsel sistemin kullanılmasıyla dört farklı kanal yolu ile gerçekleşmektedir. Fleming ve Baume (2006) bu boyutlarla öğrencilerin bilgiyi alırken hangi yolu veya yolları tercih ettiğini ortaya koymaya çalışmıştır:

- Görsel: Bilginin çizim, grafik, akışşemaları ve resim gibi sembolik ifadelerle daha kolay algılanmasinı ifade eden boyuttur.

- İşitsel: Öğrencilerin işitilen veya söylenen bilgiyi algılamaları daha kolaydır. Öğrencilerin tartışarak veya dinleyerek öğrenmede daha başarılı olduğu boyuttur.

- Okuma/Yazma: Öğrencilerin basılı kaynaklardan okuyarak veya yazarak bilgi edinmeyi tercih ettikleri ve eğitmenlerin de en çok bilgiyi sunmayı tercih ettikleri bilgiyi algılama ve yorumlama boyutudur.

- Kinestetik: Daha çok deneyim yaşayarak, gerçek ortamında veya benzerinde dokunma, hissetme, görme ve işitme, tatma gibi 
Tablo 1. Her Bir Öğrenme Tercihine ilişkin Öğrencilerin Çalışma Stratejileri

\begin{tabular}{|c|c|c|c|}
\hline & Bilgi Edinme/Alma & Sorunsuz Çalıșma & $\begin{array}{c}\text { Sınavda Başarılı } \\
\text { Olmak }\end{array}$ \\
\hline GÖRSEL & $\begin{array}{l}\text { - Farklı renklerle önemli } \\
\text { öğelerin altını çizme } \\
\text { - Şema oluşturma } \\
\text { - Resim, fotoğraf, video, } \\
\text { poster, yansı kullanma } \\
\text { - Renkli, hareketli, canlı ders } \\
\text { anlatan öğretmenle çalışma } \\
\text { - Resimli, şekilli, ders kitapları } \\
\text { kullanma } \\
\text { - Grafik, simge kullanma } \\
\text { - Aydınlık ortamda çalışma }\end{array}$ & $\begin{array}{l}\text { - İmgeleri değişik yollarla yeniden } \\
\text { oluşturun, farklı özel düzenlemeleri } \\
\text { deneyin. } \\
\text { - Sayfaları belleğinizde yeniden } \\
\text { çizin. } \\
\text { - Sözcükler yerine simgeler ya da } \\
\text { kısaltmalar kullanın. } \\
\text { - Ders notlarınızı 3:1 oranında resim } \\
\text { sayfalarına indirgeyerek, } \\
\text { anlaşılabilir paket haline getirin. }\end{array}$ & $\begin{array}{l}\text { - Konuları } \\
\text { şekillendirin. } \\
\text { - Sınava ilişkin } \\
\text { yanıtları yazın } \\
\text { - İmgelerle } \\
\text { oluşturduğunuz } \\
\text { resimleri anımsayın. } \\
\text { • Görsel edimlerinizi } \\
\text { sözcüklere } \\
\text { dönüştürmeye } \\
\text { çalışın. }\end{array}$ \\
\hline işiTSEL & $\begin{array}{l}\text { - Derslere katılın. } \\
\text { - Tartışmalara ve oturumlara } \\
\text { katılın. } \\
\text { - Konuları başkalarıyla ve } \\
\text { öğretmenle tartışın. } \\
\text { - Yeni fikirleri başkalarına } \\
\text { açıklayın. } \\
\text { - Ses kaydedici kullanın. } \\
\text { - İlginç örnekleri, öyküleri, } \\
\text { fıkraları anımsayın. } \\
\text { - Yansıları, resimleri ve diğer } \\
\text { görsel materyalleri, başkasına } \\
\text { açıklatın. } \\
\text { - Anımsamalar ve } \\
\text { tamamlamalar için notlarınızda } \\
\text { boş alanlar bırakın. }\end{array}$ & $\begin{array}{l}\text { - Dinlemeyi tercih ettiğiniz için } \\
\text { notlarınız yetersiz olabilir. } \\
\text { Başkalarıyla konuşarak ve ders } \\
\text { kitabından derlemelerle notlarınızı } \\
\text { zenginleştirmeniz gerekecek. } \\
\text { - Özet notlarınızı ses kaydına alın } \\
\text { ve dinleyin. } \\
\text { - Bir konuya ilişkin anladıklarınızı } \\
\text { başkalarına dinletin. } \\
\text { - Özet halindeki notlarınızı sesli bir } \\
\text { şekilde okuyun. } \\
\text { - Notlarınızı, bir başka işitsel } \\
\text { öğrenme tercihli birine açıklayın. } \\
\text { - Ders notlarınızı 3:1 oranında } \\
\text { azaltarak anlaşılabilir paket haline } \\
\text { getirin. }\end{array}$ & $\begin{array}{l}\text { - Sınavı veren kişiyle } \\
\text { konuşuyormuşsunuz } \\
\text { gibi düşünün. } \\
\text { - Kendi konuşmanızı } \\
\text { dinleyin ve yazın. } \\
\text { - Sakin yerlerde } \\
\text { zaman geçirin ve } \\
\text { düşüncelerinizi } \\
\text { anımsayıp } \\
\text { toparlamaya çalışın. } \\
\text { - Eski sınav sorularını } \\
\text { yazarak yanıtlamaya } \\
\text { çalışın. } \\
\text { - Yanıtlarınızı sesli } \\
\text { bir şekilde ya da } \\
\text { içinizden anlatın. }\end{array}$ \\
\hline OKU/YAZ & $\begin{array}{l}\text { - Listeler, başlıklar, sözlükler, } \\
\text { derlemeler, tanımlar, yazılı } \\
\text { notlar, ders kitapları, Okuma } \\
\text { parçaları-kütüphane. } \\
\text { - Sözcükleri iyi kullanan ve } \\
\text { notlarla tümcelere ilişkin } \\
\text { zengin birikimi olan } \\
\text { öğretmenler } \\
\text { - Makaleler }\end{array}$ & $\begin{array}{l}\text { - Notlarınızı tekrar tekrar okuyun } \\
\text { • Düşünce ve ilkeleri başka } \\
\text { sözcüklerle tekrar yazın. } \\
\text { • Şekilleri ve grafikleri anlatım } \\
\text { şeklinde düzenleyin. ( Örneğin; } \\
\text { Trend...) } \\
\text { • Tepkileri, eylemleri, şekilleri ve } \\
\text { çizimleri sözcüklere dönüştürün. } \\
\text { • Listelerinizin çoktan seçmeli } \\
\text { sorular şeklinde düzenlenmesini } \\
\text { zihninizde canlandırın ve } \\
\text { aralarındaki farkı görmeye çalışın. } \\
\text { • Notlarınızı 3:1 oranında azaltarak } \\
\text { anlaşılabilir bir pakete dönüştürün. }\end{array}$ & $\begin{array}{l}\text { - Sınavın yanıtlarını } \\
\text { yazın. } \\
\text { • Çoktan seçmeli } \\
\text { sorular üzerinde } \\
\text { çalışın. } \\
\text { - Başlangıç ve } \\
\text { sonlandırmalı } \\
\text { paragraflar yazın. } \\
\text { - Listeler yapın ( } \\
\text { a,b,c,d,1,2,3,4...). } \\
\text { • Sözcüklerinizi } \\
\text { hiyerarşik sıralama } \\
\text { çerçevesinde } \\
\text { düzenleyin. }\end{array}$ \\
\hline KINESTETIK & $\begin{array}{l}\text { - Tüm duyular } \\
\text { - Laboratuarlar, alan geziler } \\
\text { - Gerçek yaşama yakın } \\
\text { örnekler veren öğretmenler } \\
\text { - Uygulamalar } \\
\text { - El altı yaklaşımları (Bilgisayar) } \\
\text { - Deneme ve yanılma. } \\
\text { - Sergiler, örnekler, }\end{array}$ & $\begin{array}{l}\text { - Başlıklar/konular "somut” yada } \\
\text { "ilgili” olmadığından ders notlarınız } \\
\text { yeterli olmayabilir. } \\
\text { • Oluşan "gerçek” şeyleri } \\
\text { anımsayın. } \\
\text { • Özetinize çok sayıda örnek } \\
\text { ekleyin. } \\
\text { - Notlarınızla ilgili olarak “yaparak” }\end{array}$ & $\begin{array}{l}\text { - Uygulama yanıtlar, } \\
\text { paragraflar... yazın. } \\
\text { - Kendi odanızda } \\
\text { sınav durumunu } \\
\text { canlandırıp oynayın. }\end{array}$ \\
\hline
\end{tabular}




\begin{tabular}{|c|c|c|}
\hline & $\begin{array}{l}\text { fotoğraflar. } \\
\text { • Tarifler, problem çözümleri, } \\
\text { önceki sınav kağıtları. }\end{array}$ & $\begin{array}{l}\text { öğrenme tercihli başka biriyle } \\
\text { konuşun. } \\
\text { - Bir düşünceyi anlatan resim ve } \\
\text { fotoğraflar kullanın. } \\
\text { - Deneyleri, alan } \\
\text { gezilerini... anımsayın. } \\
\text { - Ders notlarını 3:1 oranında } \\
\text { azaltarak anlaşılabilir (öğrenilebilir) } \\
\text { bir paket haline getirin. }\end{array}$ \\
\hline
\end{tabular}

Kaynak: http://vark-learn.com/home-turkish/ adresinden 03.04.2019 alınmış ve kurgulanmıştır.

\section{Amaç}

$\mathrm{Bu}$ araştırmanın amacı, çevrimiçi tezsiz yüksek lisans öğrencilerinin öğrenme biçimlerinin çalışma durumları, çalışılan sektör ve günde derslerine ayırdıkları çalışma saatleri bağlamında değişip değişmediğini incelemektir. Bu amaca ulaşmak için aşağıdaki sorulara yanıtlar aranmıştır:

1. Çevrimiçi yöntemle ders alan öğrencilerin öğrenme tercihleri nelerdir?

2. Öğrencilerin çalışma durumlarına göre öğrenme tercihlerindeki durum nasıldır?

3. Öğrencilerin çalışma kurumlarına göre öğrenme tercihlerindeki durum nasıldır?

4. Öğrencilerin ders çalışma için günlük ayırdıkları süre ile öğrenme tercihlerindeki durum nasildir?

\section{Yöntem}

$\mathrm{Bu}$ araştırmada uzaktan öğrenenlerin öğrenme biçimleri ile çalışma durumları, çalışılan sektör ve günde derslerine ayırdıkları çalışma saatleri arasındaki ilişki frekans ve yüzde ifadeleri ile gösterilmiştir. Bu çerçevede araştırma tarama modelinde betimsel bir çalışmadır. Tarama modelleri, geçmişte ya da halen var olan bir durumu var olduğu şekli ile betimlemeyi amaçlayan araştırma yaklaşımıdır (Karasar, 2012).

\section{Evren ve Örneklem}

Bu araştırmanın evrenini 2018- 2019 eğitim ve öğretim yılında bir kamu üniversitenin Sosyal Bilimler Enstitüsü'ne bağlı programlarda lisansüstü düzeyde öğrenim gören öğrenciler, örneklemini ise araştırmanın amacına uygun biçimde benzeşik örnekleme yöntemiyle belirlenen enstitüye bağlı tamamen çevrimiçi yürütülen altı programda öğrenim gören öğrenciler oluşturmaktadır. Benzeşik örnekleme yönteminde örneklem, araştırmanın problemiyle ilgili olarak evrende yer alan benzeşik bir alt grubu ya da oldukça özelleşmiş bir durumu içerebilir (Strauss ve Corbin, 2014). Çevrimiçi yürütülen bu altı programda öğrenim gören öğrencilerin tamamına öğrenme yönetim sistemi üzerinden rahatça erişilebilmesinden ötürü ilgili programlardaki tüm öğrenciler araştırmaya dâhil edilmiştir.

$\mathrm{Bu}$ araştırmada örneklemin tamamına öğrenme yönetim sistemi üzerinden ulaşılmıştır. 300 kadar öğrenciye anket gönderilse de anketlere 122 öğrenci yanıt vermiştir. Yani ölçme araçlarında yer 
alan soruların yanıtlanma oranı \% 40,7'dir. Ölçek doldurulmadan önce öğrenciler çalışmanın amacı hakkında bilgilendirilmiş ve çalışmaya katılmada gönüllülük esası dikkate alınmıştır. Elde edilen veriler frekans ve yüzdelik dağılımları ile gösterilmiştir.

Tablo 2. Araştırma Katılımcılarına iliş̧kin Demografik Bilgiler

\begin{tabular}{|c|c|c|c|}
\hline Öğrenim Gördükleri Program & Sayı & Yüzde & Toplam \\
\hline Uzaktan Öğretim & 87 & 71,3 & \multirow[t]{6}{*}{122} \\
\hline Görsel iletişim Tasarımı & 16 & 13,1 & \\
\hline Pazarlama Yönetimi & 7 & 5,7 & \\
\hline Ölçme ve Veri Analitiği & 6 & 4,9 & \\
\hline İşletme Yönetimi & 4 & 3,3 & \\
\hline Konaklama İşletmeciliği & 2 & 1,6 & \\
\hline Çalışma Durumları & Sayı & Yüzde & Toplam \\
\hline Çalışıyor & 103 & 84,4 & \multirow[t]{2}{*}{122} \\
\hline Çalışmıyor & 19 & 15,6 & \\
\hline Çalıştıkları Sektör & Sayı & Yüzde & Toplam \\
\hline Kamu & 58 & 56,3 & \multirow[t]{2}{*}{103} \\
\hline Özel & 45 & 36,9 & \\
\hline Derslere ayrılan günlük saat & Sayı & Yüzde & Toplam \\
\hline 1 saatten az & 35 & 28,7 & \multirow[t]{3}{*}{122} \\
\hline 1-2 saat arası & 62 & 50,8 & \\
\hline 2 saat ve üstü & 25 & 20,5 & \\
\hline
\end{tabular}

Tablo2'de görüldüğ̈̈ üzere, araştırmaya 122 öğrenci katılmış olup, araştırmaya katılan öğrencilerin \%71,3 (87 öğrenci) gibi çok büyük bir oranı çevrimiçi uzaktan öğretim tezsiz yüksek lisans programında öğrenim gören öğrenciler oluşturmaktadır. Bunu sırasıyla \%13,1 (16 öğrenci) Görsel İletişim Tasarımı, \%5,7 (7 öğrenci) Pazarlama Yönetimi, \%4,9 (6 öğrenci) Ölçme ve Veri Analitiği, \%3,3 (4 öğrenci) İşletme Yönetimi ve \%1,6 (2 öğrenci) ile Konaklama İşletmeciliği öğrencileri oluşturmaktadır. Bu öğrencilerin \%84,4’ü (103 öğrenci) gibi çok yüksek bir oranı herhangi bir yerde çalıştıklarını, \%16,6'sı (19 öğrenci) çalışmadıklarını belirtmişlerdir. Çalışan 103 öğrencinin çalıştıkları sektör türüne bakıldığında ise \%56,3'ünün (58 öğrenci) kamuda, \%36,9'unun da (45 öğrenci) özel sektörde çalıştıkları görülmektedir. Ayrıca araştırmaya katılan öğrencilerin yaklaşık yarıs1 \%50,8 (62 öğrenci) gün içerisinde 1-2 saat arasında derslerine zaman ayırdıklarını, \%28,7'si (35 ögrenci) 1 saatten az ve \%20,5'inin de (25 öğrenci) 2 saat ve üstü zaman ayırdıklarını belirtmektedirler. Araştırmaya katılan öğrencilerin çok büyük bir oranı \%89,3 (109 öğrenci) lisans mezunu iken yüksek lisans mezunu, başka bir programda yüksek lisans öğrenimine devam eden ve hatta doktora eğitimine devam eden öğrencilerde bulunmaktadır.

\section{Veri Toplama Araci}

Bu araştırmada Neil ve Fleming tarafından 1992 yılında geliştirilen VARK Öğrenme biçimleri envanteri tercih edilmiştir. VARK Öğrenme Biçimleri bireylerin bilgi alışverişlerini nasıl yaptıklarını, bilgiyi işleme tercihlerinin neler olduğunu ortaya çıkarmayı amaçlamaktadır. VARK'`1 oluşturan 16 
envanter sorusunda farklı senaryolar yaratılarak, bireyin o durumda hangi tercihi yapacağını yanıtlaması istenir. Birey birden fazla yolu tercih edebileceğinden, birden fazla seçeneği işaretleyebilir ya da seçeneklerden hiçbirini uygun bulmuyorsa soruyu boş bırakabilmektedir (Fleming ve Mills, 1992).

Tablo 3. VARK Öğrenme Biçimleri Envanteri Örnek Sorusu Ve Çözümlemesi

\begin{tabular}{|c|c|c|c|c|}
\hline \multirow[b]{2}{*}{ Seçenek } & \multicolumn{4}{|c|}{ Soru 9} \\
\hline & \multicolumn{4}{|c|}{ Bilgisayarda yeni bir program, beceri ya da oyun öğrenmek istiyorsunuz. } \\
\hline A & \multicolumn{4}{|c|}{ Programla birlikte verilen yazılı açıklamaları/talimatları okursunuz. } \\
\hline B & \multicolumn{4}{|c|}{ Programa ilişkin bilgisi olan biriyle konuşursunuz. } \\
\hline C & \multicolumn{4}{|c|}{ Kontrol kumandalarını ya da klavyeyi kullanırsınız. } \\
\hline $\mathrm{D}$ & \multicolumn{4}{|c|}{ Konuya ilişkin verilen kitapçıktaki şekilleri izlersiniz. } \\
\hline \multirow{2}{*}{ Çözümleme } & A & B & C & $\mathrm{D}$ \\
\hline & R ( Okuma/Yazma) & A (Işitsel) & K (Kinestetik) & V(Görsel ) \\
\hline
\end{tabular}

VARK Öğrenme Biçimleri Envanterinin İngilizce metni geçerlilik güvenirlik çalışması Leite, W. L., Svinicki, M. ve Shi, Y. (2010) tarafından yapılmış olmakla birlikte Kalkan (2007) tarafından Türkçeye çevrilen envanterin Türkçe versiyonunun geçerlilik ve güvenirlik çalışması Düzgün (2018) tarafından yapılmıştır. Türkiye'nin farklı bölgelerinde görev yapan 318 öğretmen üzerinde yapılan araştırma sonuçları LISREL programında analiz edilerek doğrulayıcı faktör analizi yapılarak güvenirlik ve geçerlik değerleri elde edilmiştir. Envanterin güvenirliğini kestirebilmek amaciyla Cronbach Alpha katsayısı kullanılmıştır. Ölçeğin toplam güvenirlik katsayısı 0,76 olarak bulunmuştur. Ölçme aracının tüm boyutlarında madde-test korelasyonu 0,36 ile 0,55 arasında değişmektedir.

Araştırmanın yürütülebilmesi için ilgili kurumun Bilimsel Araştırmalar Etik Kurul'undan gerekli izin alınmıştır. Çalışmanın yapılabilmesi için de ilgili programların bölüm başkanlarından sözlü izin alınmıştır.

\section{BULGULAR}

Bu bölümde araştırmanın alt problemlerine ilişkin bulgular ve açıklamalara yer verilmiştir.

Araştırmanın birinci alt problemine ilişkin çevrimiçi yöntemle ders alan öğrencilerin öğrenme biçimlerinin dağılımı Şekil 1'de gösterilmektedir. 


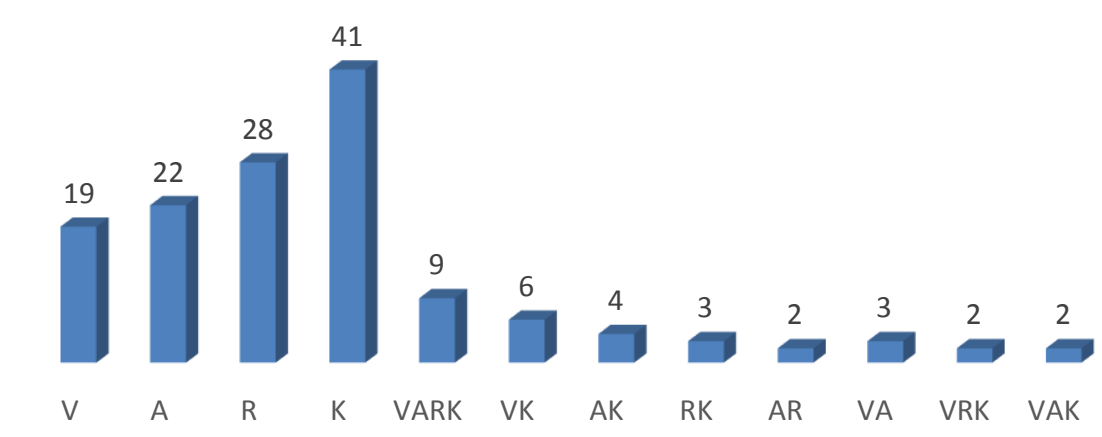

Şekil1. Çevrimiçi yöntemle ders alan öğrencilerin öğrenme biçimlerinin dağılımı

Şekil 1'de görüldüğü gibi araştırmaya katılan 122 öğrencinin toplamda 140 adet farklı öğrenme biçiminde bulunduğu görülmektedir. Bunun sebebi öğrencilerden bazılarının birbirinden farklı (Tekli [V], Çoklu [VRK], Tekli/Tekli [V, K], Tekli/Çoklu [A, RK], Çoklu/Çoklu [AR, VK]) öğrenme biçimi tercih etmesindendir. Öğrencilerin en çok tercih ettiği öğrenme biçiminin (41 öğrenci) Kinestetik (K) öğrenme biçimi olduğu görülmektedir. Bunu sırasıyla 28 öğrenci okuma/yazma (R), 22 öğrenci işitsel (A) ve 19 öğrenci görsel (V) öğrenme biçimleri takip etmektedir. Genel olarak öğrencilerin çoklu öğrenme biçimleri tercihinde de bulundukları görülmektedir. Çoklu öğrenme biçimleri içerisinde en çok VARK (Görsel, İşitsel, Okuma-yazma, Kinestetik) öğrenme biçiminin olduğu görülmektedir.

Araştırmanın ikinci alt problemine göre, öğrencilerin çalışma durumlarına göre öğrenme biçimlerindeki duruma ilişkin dağılım Şekil 2'de gösterilmektedir.

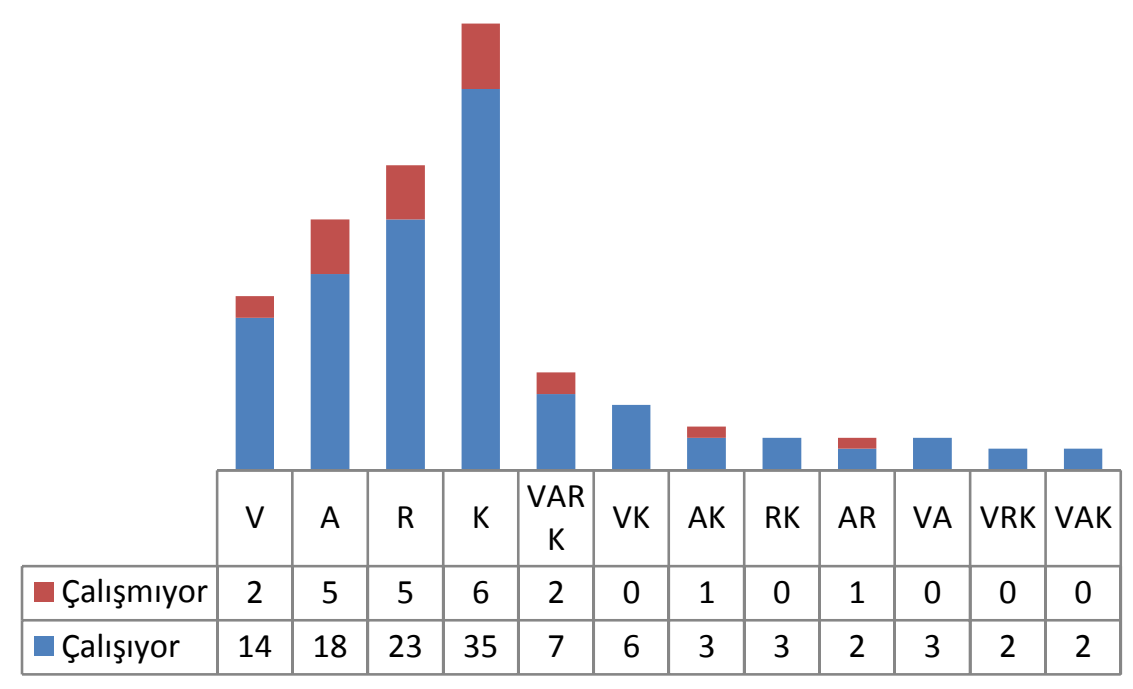

Şekil 2. Öğrencilerin öğrenme biçimlerinin çalışma durumlarına ilişkin dağılımı 
Araştırmaya katılan öğrencilerin \%84,4’ü (103 öğrenci) gibi çok yüksek bir oranı herhangi bir yerde çalıştıklarını, \%16,6'sı (19 öğrenci) çalışmadıklarını belirtmişlerdir. Şekil 2'de, bu 122 öğrencinin belirlediği 140 öğrenme tercihlerinin dağılımında değişim olduğu görülmektedir. Çalıştı̆̆ını belirten 103 öğrencinin 35'i (K), 23'ü (R), 18'i (A) ve 14'ü de (V) öğrenme biçimi tercihinde bulunmuştur. Çalıştığını belirtenlerin içerisinde çoklu öğrenme tercihinde bulunan öğrencilerde bulunmaktadır. Çoklu öğrenme tercihleri içerisinde en çok VARK ve VK tercihleri görülmektedir. Çalıştığını belirtenlere benzer şekilde herhangi bir yerde çalışmadığını yani sadece öğrencilik yaptığını belirten öğrencilerde sırayla $\mathrm{K}, \mathrm{R}, \mathrm{A}$ ve $\mathrm{V}$ öğrenme biçimi tercihlerinde bulunmuşlardır.

Araştırmanın üçüncü alt problemine ilişkin, öğrencilerin çalıştıkları sektöre göre öğrenme biçimlerindeki dağılım Şekil 3'de gösterilmektedir.

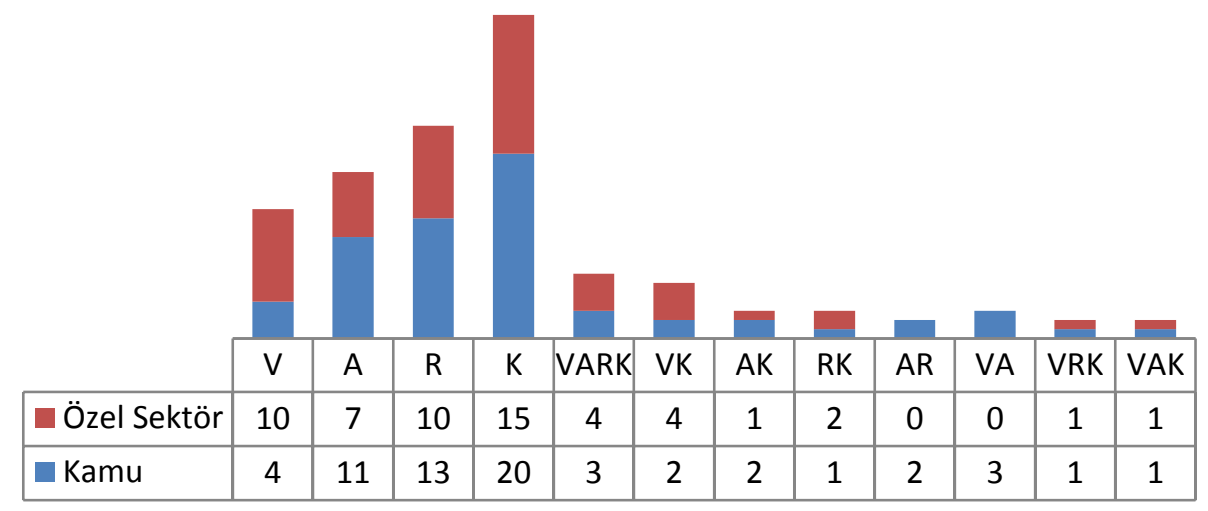

Şekil 3. Öğrencilerin çalıştıkları sektöre göre öğrenme tercihleri dağı̆ımı

Çalışan 103 öğrencinin çalıştıkları sektör türüne göre \%56,3'ünün (58 öğrenci) kamuda, \%36,9'unun da (45 öğrenci) özel sektörde çalıştıkları görülmektedir. Şekil 3'de, bu 103 öğrencinin belirlediği 118 öğrenme biçimlerinin dağılımında değişim olduğu görülmektedir. Kamu alanında çalışanların en çok tercih ettikleri öğrenme biçimi K iken bunu sırasıyla R, A ve V takip etmektedir. Özel sektörde çalıştığını belirten öğrencilerinde en çok tercih ettikleri öğrenme biçimi K iken V ve R biçimleri eşit seviyede ve A bunların ardından tercih edilen öğrenme biçimi olmuştur.

Araştırmanın dördüncü alt problemine ilişkin öğrencilerin öğrenme biçimlerinin programlarındaki derslere günde ayırdıkları süre açısından dağılımı Şekil 4'te gösterilmektedir. 


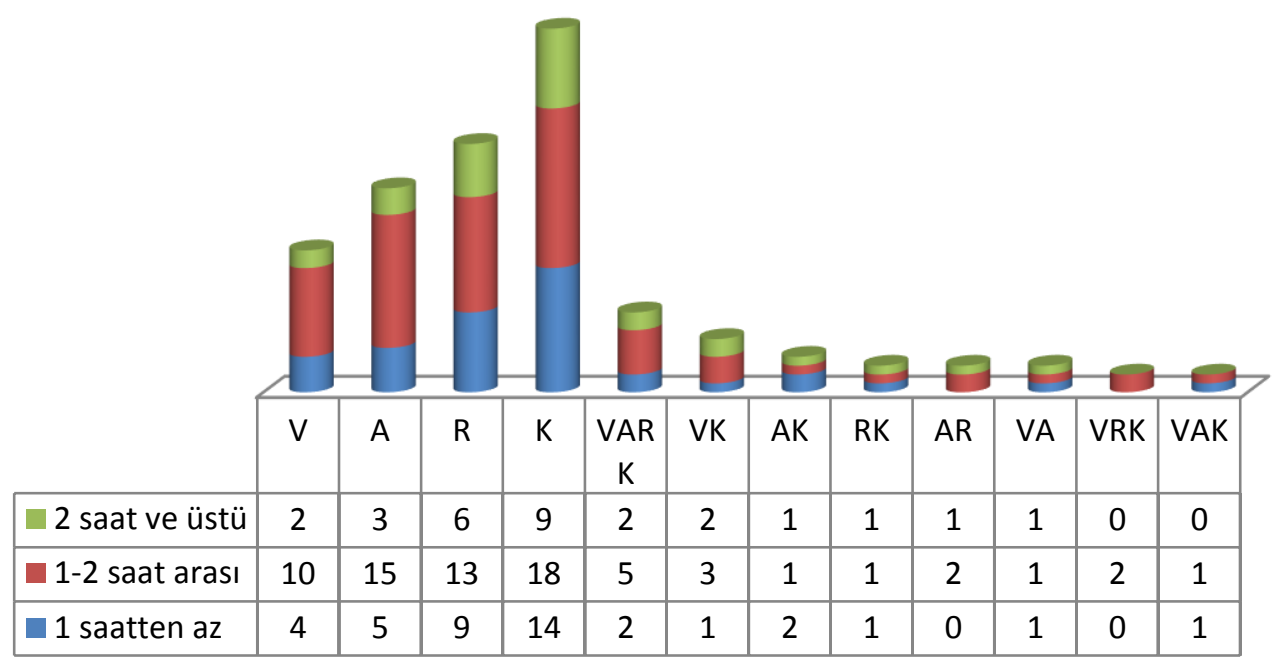

Şekil 4. Öğrencilerin öğrenme biçimlerinin derslerine günde ayırdıkları süre bağlamında dağııımı

Araştırmaya katılan öğrencilerin yaklaşık yarısı \%50,8 (62 öğrenci) gün içerisinde 1-2 saat arasında derslerine zaman ayırdıklarını, \%28,7'si (35 öğrenci) 1 saatten az ve \%20,5'inin de (25 öğrenci) 2 saat ve üstü zaman ayırdıklarını belirtmektedirler. Şekil 4'te görüldüğü derslerine günde 1 saatten az zaman ayırabilen, 1-2 saat arası zaman ayırabilen ve 2 saat ve üstü zaman ayırabilen öğrencilerin tümünde en çok tercih edilen öğrenme biçimi $K$, bunu sırasıyla $R$, A ve $V$ takip etmektedir.

\section{Tartışma}

$\mathrm{Bu}$ çalışma çevrimiçi yöntemle yürütülen tezsiz yüksek lisans programlarında öğrenim gören öğrencilerinin öğrenme biçimlerinin ortaya çıkarılması amacıyla yapılmıştır. Bozkurt ve Orak (2016) 2000-2013 yılları arasında Türkiye'de öğrenme stilleriyle ilgili yapılan çalışmalarda öğrenme biçimlerinin hangi değişkenlerle çalışıldığını belirlediği belgesel tarama çalışmasında en çok sırasıyla cinsiyet, tutum, beceri, sosyo-ekonomik düzey, yaş ve motivasyon değişkenlerinin incelendiğini belirlemiştir. Slater, Lujan ve Dicarlo (2007) ve Baykan ve Nacar'ın (2007) tıp fakültesi öğrencilerinin öğrenme biçimlerini pür cinsiyet bağlamında incelediği araştırmaları da bulunmaktadır. Bu araştırma ise yaygın kullanımdan farklı olarak öğrencilerin çalışıp çalışmama durumu, çalışılan sektör ve günde ders çalışmaya ayrılan süre açısından herhangi bir farkın olup olmadığının tespit edilmesi ile diğer araştırmalardan farklılaşmaktadır.

Araştırmaya altı farklı çevrimiçi tezsiz yüksek lisans programından 122 öğrenci katılmıştır. Türkiye'de öğrenme biçimlerinin belirlenmesine ilişkin çalışmaların en çok yapıldığı grup yükseköğretim olduğu (Bozkurt ve Orak, 2016) durumuyla benzer biçimde bu araştırmada da yükseköğretim öğrencileri ile çalışılmıştır. Bu 122 öğrenci 140 farklı öğrenme biçimi tercihinde bulunmuşlardır. Baskın öğrenme biçiminin $\mathrm{K}$ olduğu görülmüştür. Araştırmaya en çok katılım 
sağlayan gruplar uzaktan öğretim ve görsel iletişim tasarımı programları öğrencileridir. Bu programlar daha çok uygulamalı disiplinlerden oluşmaktadır. Öğrenim görülen programın içerik biçiminden ötürü sonucun bu şekilde çıkması beklenmekte olan bir durumdur. Benzer şekilde Işı1dar, Aktaş ve Kurgun (2016) tarafından turizm öğrencilerinin öğrenme biçimlerinin belirlendiği araştırmada da daha çok yaparak öğrenmeyi ifade eden K öğrenme biçiminin baskın olduğu görülmüştür. Benzer şekilde Idrizi, Filiposka ve Trajkovik (2018) tarafından VARK öğrenme biçimleri envanteri ile çevrimiçi öğrenenlerin öğrenme ortamlarında kullanılan materyallere (video, PDF, interaktif video kanalı) ilişkin dağılımlarının araştırıldığı çalışmada da en baskın biçim K olarak belirlenmiştir. Karabörklü Argut vd. (2017) tarafından Sağlık Bilimleri fakültesi öğrencilerinin öğrenme stillerinin belirlendiği araştırmada da katılımcıların çoğunluğunun $\mathrm{K}$ öğrenme biçimini tercih ettikleri görülmüştür. Ama Pirondini ve Otacioğlu'nun (2018) profesyonel müzik eğitimi alan lisans öğrencilerinin öğrenme stillerini belirledikleri araştırmada öğrencilerin çoğunluğunun baskın öğrenme biçiminin $\mathrm{V}$, bunu sırasıyla $\mathrm{A}, \mathrm{K}$ ve R takip ettiği görülmüştür.

$\mathrm{Bu}$ araştırmada öğrencilerin çoklu öğrenme biçimleri tercihinde de bulundukları belirlenmiştir. Çoklu öğrenme biçimleri içerisinde en çok VARK (Görsel, İşitsel, Okuma-yazma, Kinestetik) öğrenme biçiminin olduğu görülmektedir. Benzer şekilde Iş̧1dar, Aktaş ve Kurgun'un (2016) araştırmasında da VARK çoklu öğrenme biçimine sahip bireylerin olduğu görülmüştür.

Araştırmaya katılan öğrencilerin \%84,4'ü (103 öğrenci) gibi çok yüksek bir oranı herhangi bir yerde çalıştıklarını, \%16,6’sı (19 öğrenci) çalışmadıklarını belirtmişlerdir. Araştırma lisansüstü programda öğrenim gören öğrencilerle yapıldığından yüksek bir oranının çalışan öğrenciler olması beklenebilen bir durum olarak düşünülebilir. Çalıştığını belirten 103 öğrencinin 35'i (K), 23'ü (R), 18'i (A) ve 14'ü de (V) öğrenme biçimi tercihinde bulunmuştur. Bu durum Knowles, Holton ve Swanson'un (2005) “yetişkinler, öğrenmelerini yaşamsal-merkezli bir çerçevede gerçekleştirmek isterler" varsayımı ile uyum göstermektedir. Çalıştığını belirtenlerin içerisinde çoklu öğrenme tercihinde bulunan öğrencilerde bulunmaktadır.

Çalışan 103 öğrencinin çalıştıkları sektör türüne göre \%56,3’ünün (58 öğrenci) kamuda, \%36,9'unun da (45 öğrenci) özel sektörde çalışmaktadırlar. Çalıştığını belirten bu 103 öğrenci 118 öğrenme biçimi tercihinde bulunmuştur. Kamu ve özel sektörde çalışanların en çok tercih ettikleri öğrenme biçimi K'dır. Yetişkin öğrenenlerin uygulamada elde ettikleri tecrübelerini öğrenme ortamlarına aktardığı bilgisi ile böylesi bir sonucun ortaya çıkması uyum göstermektedir.

Araştırmaya katılan 122 öğrencinin 62'si gün içerisinde 1-2 saat arasında derslerine zaman ayırırken, 35 öğrenci 1 saatten az ve 25 öğrenci de 2 saat ve üstü zaman ayırdıklarını belirtmişlerdir. Öğrencilerin tamamının, öğrenim gördükleri programlardaki derslerine her gün zaman ayırabilmeleri iki açıdan önemli görülmelidir. Birincisi öğrencilerin programa dair olumlu tutuma sahip olabilecekleri ikincisi de öğretim süreci içerisinde yerine getirilmesi gereken ödev, makale yazma, 
gerekli okumalar, projeler, çizimler vs. sorumlulukların gerçekleştirilmeden öğrenmenin sağlanamayacağı anlayışına öğrencilerin sahip olmasıdır.

Sonuç olarak, öğrenme biçimlerine ilişkin çeşitli değişkenler ile karşılaştırmaların yapıldığ 1 araştırmalar bulunmaktadır. Yapılan alanyazın taramalarında bu araştırmada kullanılan değişkenler ile yapılmış olan çalışmalara rastlanmaması nedeni ile araştırmanın özgün bir çalışma olduğu sonucu çıkarılabilir. Çevrimiçi yöntemle yürütülen tezsiz yüksek lisans programlarında öğrenim gören öğrencilerin öğrenme biçimlerini belirlemek ve bunu çalışma durumu, çalış1lan sektör ve günde derslerine ne kadar zaman ayırdıkları değişkenleri ile karşılaştırmayı amaçlayan bu çalışma, sadece VARK öğrenme biçimi envanteri kullanılarak gerçekleştirilmiştir. Farklı modellerin kullanılması, araştırma örnekleminin ve değişkenlerin artırılması bu alanda çalışma yapacak araştırmacılara ve alanyazına katkı sağlayacaktır.

Yetişkin grubuna dâhil edebileceğimiz lisans üstü öğrenenlerin yetişkin öğrenme (androgoji) özellikleri ile kendileri için uygun gördükleri öğrenme biçimlerine ilişkin özelliklerin bilinmesi yani eğitim ortamlarının öğrencilerinin öğrenme biçimleri dikkate alınarak düzenlenmesi ve eğitim ortamlarında öğrencilerin sahip oldukları öğrenme biçimlerine yönelik çalışmalara yer verilmesi etkin bir öğrenme için önemli olduğu düşünülmektedir. Öğrencilerin yatkın oldukları öğrenme biçiminin bilincinde olmalarının derse yaklaşımlarını olumlu yönde etkileyeceğini, öğrenme için harcadıkları çabayı ve zamanı azaltarak ders başarısını artırabileceği düşünülmektedir. Eğitimcilerin öğrenme biçimleri konusunda bilgi sahibi olmasının da aynı zamanda uygun teknik ve materyallerin kullanımı ve kişisel gelişim açısından önemli olacağı düşünülmektedir. 


\section{Kaynakça}

Argut, S. K., Mustafaoğlu, R., Kuş, G., \& Özdinçler, A. R. (2017). Determination of learning style preferences in students at the faculty of health sciences. Clinical And Experimental Health Sclences, 7(4), 146-151.

Bahadori, M., Sadeghifar, J., Tofighi, S., Mamikhani, J. A ve Nejati, M. (2011). Learning styles of the health services management students: A study of first-year students from the medical science universities of Iran, Australian Journal of Basic and Applied Sciences, 5 (9): 122-127.

Baykan, Z. ve Nacar, M. (2007). Learning styles of first-year medical students attending Erciyes University in Kayseri, Turkey. Advances in physiology education; 31: 158-60.

Bozkurt, O. ve Orak, Z. (2016). Türkiye'de akademik başarı değişkeni alanında yapılan öğrenme stilleriyle ilgili çalışmaların incelenmesi. Mustafa Kemal Üniversitesi Sosyal Bilimler Enstitüsü Dergisi, 13 (35). http://dergipark.gov.tr/mkusbed/issue/24546/259986 [Erişim Tarihi: 08.02.2019]

Düzgün, S. (2018). Türkçeye çevrilmiş vark öğrenme stilleri envanterinin doğrulayıcı faktör analizi modeli ile doğrulanması: öğretmenler örneği. Electronic Turkish Studies, 13(11).

Fleming, N. D. ve Baume, D. (2006). Learning styles again: VARKing up the right tree!. Educational Developments, SEDA Ltd, 7 (4): 4-7.

Fleming, N. D. (1995) "I'm different; not dumb. Modes of presentation (VARK) in the tertiary classroom in Zelmer,A.", (ed.) Research and Development in Higher Education, Proceedings of the 1995 Annual Conference of the Higher Education and Research Development Society of Australasia (HERDSA),HERDSA, c. 18, ss. 308 -313 .

Fleming, N. D. ve Mills, C. (1992). Not another inventory, rather a catalyst for reflection. To Improve the Academy, 11: 137-155.

Grasha, A. F. (1996). Teaching with style: a practical guide to enhancing learning by understanding teaching and learning styles. Pittsburgh: Alliance Publishers, pp.154-158.

Gregorc, A. F. (1979). Learning/ teaching styles: their nature and effects. In student learning styles: diagnosing and prescribing program. Reston. VA: National Association of Secondary School Principals, U.S.A.

Hunt, D. E. (Eds.). (1979). Learning style and student needs: an introduction to conceptual level. Reston, VA: National Association of Secondary School Principals.

Idrizi, E., Filiposka, S. and Trajkovik, V. (2018). VARK Learning Styles and Online Education: Case Study. ETAI 2018 At: Struga, R.Macedonia

Işı1dar, P , Aktaş, E , Kurgun, O . (2016). Turizm öğrencilerinin vark öğrenme modeline göre öğrenme stillerinin belirlenmesi: lisans ve ön lisans karşılaş̧ırması. Dokuz Eylül Üniversitesi Sosyal Bilimler Enstitüsü Dergisi, 18 (1), 91-113. Do1: 10.16953/Deusbed.38293

Karasar, Niyazi. (2013). Bilimsel araştırma yöntemi, Nobel Yayın Dağıtım, Ankara.

Keefe, J. W. (1979). Learning style: an overview. In national association of secondary school principals (ed.), Student learning styles: Diagnosing and prescribing programs, 1-17.

Kinshuk, Liu, T., \& Graf, S. (2009). Coping with mismatched courses: students' behaviour and performance in courses mismatched to their learning styles. Education Technology Research and Development, 57, 739-752.

Knowles, M. S., Holton, E. F. \& Swanson, R. A. (2005). The adult learner 6th edition. Burlington, MA: Elsevier.

Kocaarslan Pirondini, B. \& Gürşen Otacıoğlu, S. (2018). "Profesyonel müzik eğitimi alan lisans öğrencilerinin bilinçli farkındalık düzeyleri ve öğrenme stilleri arasındaki ilişki”, International Social Sciences Studies Journal, 4(24): 5231-5244

Kolb, D.A. (1984), Experiental learning: experiences as the source of learning and development, Englewood Cliffs, NJ: Prentice Hall, INC.

Leite, W. L., Svinicki, M. ve Shi, Y. (2010). Attempted validation of the scores of the VARK: Learning styles inventory with multitrait-multimethod confirmatory factor analysis models. Educational and psychological measurement, 70: 323-339. 
Muğan, C. Ş ve Akman, N. H. (2004). "Muhasebe Eğitiminde Öğretim Ve Öğrenim Yöntemleri ile Ders Başarısı Arasındaki ilişki: Pilot Çalışma”. <http://www.isletme.istanbul.edu.tr/surekli_yayinlar/tmes2004/tmes_2004.pdf [Erişim Tarihi: 15.01.2008].

Saeed, N., Yang, Y. \& Sinnappan, S. (2009). Emerging web technologies in higher education: a case of incorporating blogs, podcasts and social bookmarks in a web programming course based on students' learning styles and technology preferences. Educational Technology \& Society, 12(4), 98-109.

Silver, H., Strong, R. ve Perini, M. (1997) “Integrating learning styles and multiple intelligences”, Educational Leadership, c. 55, s. 1, ss. 22-27.

Slater, J. A., Lujan, H. L, and DiCarlo, S. (2007). Does gender influence learning style preferences of first year medical students? Advances in physiology education, 31(4), 336-342.

Strauss, A. \& Corbin, J. (2014). Basics of qualitative research techniques. Sage Publications, New York.

Topçu, A. (2008). 'Intentional repetition' and learning style: Increasing efficient and cohesive interaction in asynchronous online discussions. British Journal of Educational Technology, 39(5), 901-919.

Ülgen, G. (1995). Ĕ̈itim psikolojisi-birey ve öğrenme. Ankara. 